\title{
'Garnem' and Myrobalan 'P.2175': Two Different Drought Responses and Their Implications in Drought Tolerance
}

\author{
Beatriz Bielsa ${ }^{1}$ D , María Ángeles Sanz ${ }^{2,3}$ and María José Rubio-Cabetas ${ }^{1,3, *}$ \\ 1 Unidad de Hortofruticultura, Centro de Investigación y Tecnología Agroalimentaria de Aragón (CITA), \\ Avda. Montañana 930, 50059 Zaragoza, Spain; bbielsa@cita-aragon.es \\ 2 Área de Laboratorios de Análisis y Asistencia Tecnológica, Centro de Investigación y Tecnología \\ Agroalimentaria de Aragón (CITA), Avda. Montañana 930, 50059 Zaragoza, Spain; masanzg@aragon.es \\ 3 Instituto Agroalimentario de Aragón-IA2 (CITA-Universidad de Zaragoza), 50013 Zaragoza, Spain \\ * Correspondence: mjrubioc@cita-aragon.es; Tel.: +34-976-716610
}

check for updates

Citation: Bielsa, B.; Sanz, M.Á.; Rubio-Cabetas, M.J. 'Garnem' and Myrobalan 'P.2175': Two Different Drought Responses and Their Implications in Drought Tolerance. Horticulturae 2021, 7, 299. https:/ / doi.org/10.3390/horticulturae7090299

Academic Editor: Rossano Massai

Received: 13 July 2021

Accepted: 7 September 2021

Published: 9 September 2021

Publisher's Note: MDPI stays neutral with regard to jurisdictional claims in published maps and institutional affiliations.

Copyright: (c) 2021 by the authors. Licensee MDPI, Basel, Switzerland. This article is an open access article distributed under the terms and conditions of the Creative Commons Attribution (CC BY) license (https:/ / creativecommons.org/licenses/by/ $4.0 /)$.

\begin{abstract}
One of the challenges in rootstock breeding programs is the combination of tolerances to different abiotic stresses in new interspecific hybrids adapted to a wide range of environmental conditions. In this work, two Prunus L. rootstocks: Myrobalan 'P.2175' (P. cerasifera Ehrh.) and the almond $\times$ peach hybrid 'Garnem' (P. amygdalus Batsch $\times$ P. persica (L.) Batsch) were subjected to drought during $24 \mathrm{~h}$ to understand their drought response mechanisms. The study was conducted monitoring leaf water potential (LWP), stomatal conductance (gs), relative water content (RWC), and electrolyte leakage (EL); as well as the abscisic acid (ABA) content in roots. The relative expression of five drought-relative genes was also studied. The obtained results allowed examining the drought tolerance potential of 'Garnem' and Myrobalan 'P.2175', demonstrating the great potential of 'Garnem' as drought tolerance source in future selections in breeding. Furthermore, based on the obtained data, the transcription factor Myb25-like could be a good biomarker of drought sensitivity for use in Prunus rootstock breeding programs.
\end{abstract}

Keywords: abscisic acid; osmotic adjustment; Prunus spp.; rootstock; stomatal regulation; water stress

\section{Introduction}

Prunus L. is an economically important genus, which includes approximately 200 species, most of which are cultivated in the temperate zone, and some in the tropical and subtropical regions [1]. Prunus species cultivated for commercial production requires the use of rootstocks derived from different members of the same genus. Rootstocks are responsible for water and nutrient uptake, as well as being able to adapt to different environmental conditions and agronomic practices [2]. Almond $\times$ peach hybrids such as 'Garnem', 'Felinem', and 'Monegro' (which derive from the cross 'Garfi' $\times$ 'Nemared') show high vigor, resistance to nematodes, as well as good adaptation to calcareous soils [3]. Currently, the goal in Prunus rootstock breeding programs is the selection of a new generation of interspecific hybrids by crossing almond $\times$ peach hybrids with plum genotypes to incorporate a higher number of abiotic tolerances, offering new challenges in Prunus breeding programs [4].

Climate warming impacts negatively by increasing the frequency of extreme drought periods [5] and causing changes in regional climates, such as in the Mediterranean basin, where water scarcity is becoming more and more severe [6]. These adverse conditions prejudice crop growth and yield. Therefore, selection of rootstocks adapted to drought conditions is crucial.

In plants, the reduction in water availability produces a drop in hydraulic conductivity in the roots that prepares the plant for water deficit conditions, increasing resistance to water flow and, thus, reducing evaporation losses [7]. Under drought stress, plants trigger different response mechanisms associated with the regulation of different physiological and 
biochemical processes, affecting plant morphology. By regulation of stomatal closure and an osmotic adjustment, a decrease in leaf expansion and photosynthetic activity occurs, and growth is regulated to minimize water loss [8-11]. This physiological response has been studied through numerous parameters including stomatal conductance (gs), leaf water potential (LWP), leaf relative water content (RWC), and cell membrane stability (CMS) and their relationships, which give a significant overview of the capability to tolerate the drought stress for the plant [11-13]. Abscisic Acid (ABA) signaling is one of the most important pathways that regulates stomatal closure [14] and induces the expression of diverse drought-responsive genes with protective functions [15]. This phytohormone is accumulated firstly in roots exposed to drought stress. Then, ABA acts as a root-toshoot signaling molecule transporting the stress signal to the leaves promoting stomatal closure $[16,17]$. In addition, ABA triggers a cascade of molecular processes that allow the maintenance of the cellular homeostasis, leading to the drought adaptation of the plant $[15,18,19]$. These processes involve regulatory genes such as transcription factors (TFs), kinases and phosphatases, and enzymes for phytohormones biosynthesis; and effector genes including chaperones, late embryogenesis abundant (LEA) proteins, enzymes for osmolytes biosynthesis, and water channel proteins $[15,20]$.

The purpose of the present work was to characterize the different physiological, biochemical, and molecular responses to drought stress and the capability of adaptation in two Prunus genotypes: the drought-tolerant hybrid 'Garnem', and the drought-sensitive plum Myrobalan 'P.2175'. This study will allow the evaluation of the potential of both genotypes as parental material in the selection of new Prunus rootstocks tolerant to drought stress.

\section{Materials and Methods}

\subsection{Plant Material and Stress Conditions}

A total of 28 plants from the almond $\times$ peach hybrid [P. amygdalus Batsch $\times$ P. persica (L.) Batsch] 'Garnem' and 20 plants from the Myrobalan plum 'P.2175' (P. cerasifera Ehrh.) were considered for the experiment. This plant material was in vitro propagated at the CITA (Agrifood Research and Technology Centre of Aragon) facilities in Zaragoza, Spain. After the in vitro step, the plants were maintained in $20-\mathrm{cm}$ diameter pots with a mix of turf, 30\% coconut fiber, and $20 \%$ sand, in a greenhouse at CITA facilities $\left(41^{\circ} 43^{\prime} 28.6^{\prime \prime} \mathrm{N}, 0^{\circ} 48^{\prime} 31.1^{\prime \prime} \mathrm{W}\right)$, for six months until the drought experiment for their acclimation. One month before the experiment, the plants were placed in 20-cm diameter pots with perlite [21] and maintained in a growth chamber with a temperature regime of $20 / 10^{\circ} \mathrm{C}$ (day/night) and a 16-h photoperiod. Light was provided by cool white fluorescent tubes, $17 \mu \mathrm{mol} \mathrm{m} \mathrm{m}^{-2} \mathrm{~s}^{-1}$. During this month, the frequencies of the irrigation and fertilization were daily (discharge rate $2 \mathrm{~L} \mathrm{~h}^{-1}$-dry irrigation system) and twice a month, respectively, for maintaining good water and nutrient status.

Drought treatment was performed with an experiment design of two randomized blocks: control (16 plants from 'Garnem'-12 plants from Myrobalan 'P.2175') and stressed (12 plants from 'Garnem'- 8 plants from Myrobalan 'P.2175'). The experiment was carried out in the same growth chamber keeping the light and temperature conditions. Plants from the control group were watered until field capacity to maintain soil water content throughout the experiment, while stressed plants were not irrigated for $24 \mathrm{~h}$. Samples of root tissue were collected from the control and stressed plants at $0 \mathrm{~h}, 3 \mathrm{~h}$, and $24 \mathrm{~h}$ of the drought stress period (Figure 1). These samples were immediately frozen at $-80{ }^{\circ} \mathrm{C}$ for subsequent analysis: ABA content determination and a gene expression study.

\subsection{Plant Water Status Evaluation}

The plant water status was controlled by four physiological parameters: leaf water potential (LWP), stomatal conductance (gs), relative water content (RWC), and electrolyte leakage (EL) in control and drought-stressed plants at three time points: $0 \mathrm{~h}, 3 \mathrm{~h}$, and $24 \mathrm{~h}$ of the drought experiment. LWP was measured in duplicate in leaves using a Scholander-type pressure chamber (Soil Moisture Equipment Corp., Santa Barbara, CA, USA) [22]. Stomatal 
conductance was also determined from the leaf of each plant with a Leaf Porometer (Decagon Devices Inc., Pullman, WA, USA). RCW was determined in duplicate as per previously published methods [23]. RWC was calculated following the Equation (1):

$$
\mathrm{RWC} \%=\frac{\mathrm{W}-\mathrm{DW}}{\mathrm{TW}-\mathrm{DW}} \times 100 .
$$

EL percentage was measured from cell membrane stability (CMS) rate. CMS was evaluated in duplicate following previously published protocols [24]. Then, CMS and EL parameters were calculated according to the following Formulas (2) and (3):

$$
\begin{aligned}
& \mathrm{CMS} \%=\frac{1-\frac{\mathrm{T} 1}{\mathrm{~T} 2}}{1-\frac{\mathrm{C} 1}{\mathrm{C} 2}} \times 100, \\
& \mathrm{EL} \%=100-\mathrm{CMS} \% .
\end{aligned}
$$

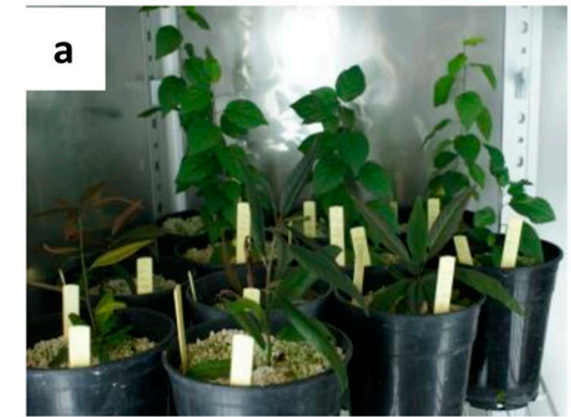

$\mathrm{Oh}$

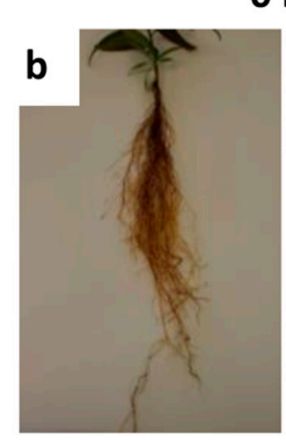

'Garnem'

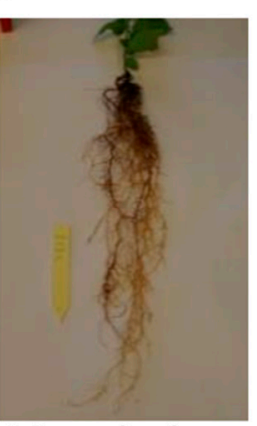

Myrobalan 'P.2175'
$3 \mathbf{h}$

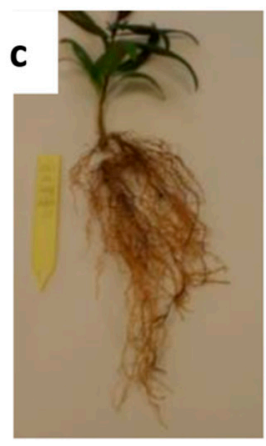

'Garnem'

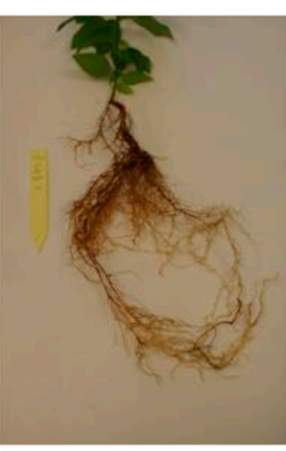

Myrobalan 'P.2175'

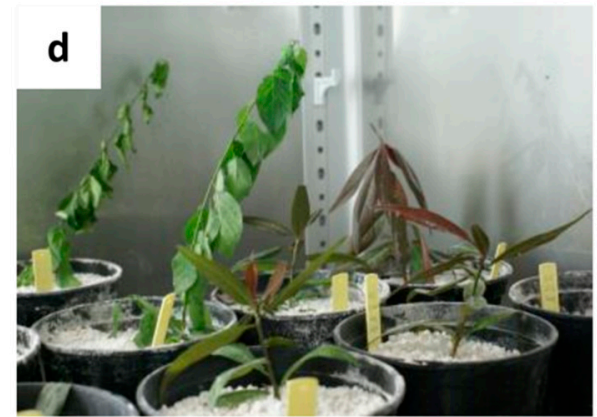

$24 \mathrm{~h}$

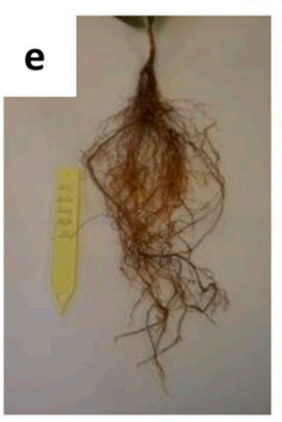

'Garnem'

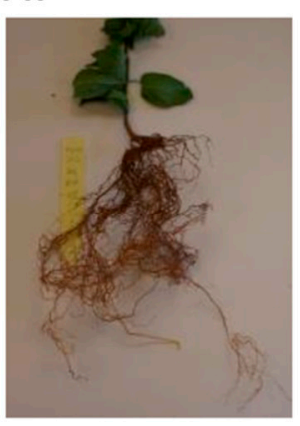

Myrobalan 'P.2175'

Figure 1. Representative images of the water status of the stressed plants of the studied genotypes ('Garnem' and Myrobalan 'P.2175') throughout the drought experiment for each time-point: (a) aerial part and (b) roots at $0 \mathrm{~h}$; (c) rooted parts at $3 \mathrm{~h}$; and (d) aerial part and (e) roots at $24 \mathrm{~h}$.

\subsection{Abscisic Acid Determination}

ABA extraction: Abscisic acid (ABA) was extracted from lyophilized root samples, which were homogeneously grinded in a 6875 Freezer/Mill ${ }^{\circledR}$ High Capacity Cryogenic Grinder (SPEX ${ }^{\circledR}$ SamplePrep, Inc., Stanmore, UK) with liquid nitrogen. ABA extraction was performed following the instructions detailed in Bielsa et al. [12].

ABA determination by mass spectrometry: ABA identification and quantification by mass spectrometry was performed in an ACQUITY-TQD tandem quadrupole mass spectrometer (Waters) following the instructions detailed in Bielsa et al. [12].

ABA analysis was carried out in MRM (Multiple Reaction Monitoring) mode, monitoring the transactions for $\left[{ }^{2} \mathrm{H}_{6}\right]-\mathrm{ABA}$ and $\mathrm{ABA}$ at $m / z 269 \rightarrow 159,225$; and $263 \rightarrow 153$, 
219, respectively. The raw data were compiled and processed with a MassLynx 4.1 software (Waters).

ABA quantification: The standard addition method was used. Aliquots of the extract obtained were added ABA standard in a concentration of $0,0.05,0.1$, and $0.25 \mathrm{ng}_{\mu \mathrm{L}}^{-1}$. A concentration of $0.1 \mathrm{ng} \mu \mathrm{L}^{-1}\left[{ }^{2} \mathrm{H}_{6}\right]-\mathrm{ABA}$ was added as internal standard, which was prepared according to Gómez-Cadenas et al. [25].

\subsection{RNA Extraction and Gene Expression Analysis}

A total of $0.5 \mathrm{~g}$ of root tissue for each time point was used for the total RNA extraction following the CTAB method described previously [26] with minor modifications [27-29]. Extracted RNA was quantified using a NanoDrop ${ }^{\circledR}$ ND-1000 UV-vis spectrophotometer (NanoDrop Technologies, Wilmington, DE, USA). RNA integrity was verified by electrophoresis on a $1 \%$ agarose gel. DNase I (TURBO DNA-free ${ }^{\mathrm{TM}}$, Ambion, Life Technologies, Carlsbad, CA, USA) was used to remove contaminating genomic DNA following the manufacturer's instructions. cDNA was synthesized from $2500 \mathrm{ng}$ of RNA utilizing SuperScript III First-Strand Synthesis System (Invitrogen, Life Technologies) in a total volume of $21 \mu \mathrm{L}$ according to the manufacturer's instructions.

Two microliters of $30 \times$ dilution of the synthesized cDNA were applied for each amplification reaction in a final volume of $10 \mu \mathrm{L}$. qRT-PCR was performed in triplicate for each of the two biological replicates on an Applied Biosystems 7900HT Fast PCR System using iTAQTM Universal SYBR Green Supermix (Bio-Rad, Hercules, CA, USA). The amplification conditions consisted of an initial denaturation at $95^{\circ} \mathrm{C}$ for $10 \mathrm{~min}$, followed by 40 cycles of $15 \mathrm{~s}$ at $95^{\circ} \mathrm{C}$ for denaturation, and $1 \mathrm{~min}$ at $60^{\circ} \mathrm{C}$ for annealing and extension. Amplification was followed by melting curve analysis by evaluating the specificity of the PCR reaction. Primers for a translocation elongation factor gene (TEF2), designed from the available P. persica TEF2 DNA sequence (Gene Bank accession number TC3544), were used as an internal reference control reaction for the qRT-PCR experiments. The specific primers for the five drought-related genes studied are listed in Table 1. Relative gene expression was quantified by performing the relative standard curve procedure. For amplification efficiency determination, the slope of the standard curves for both housekeeping and target genes was used. The standard curves were obtained from a 5-fold dilution series of a pool of the cDNA samples.

Table 1. Primer sequence list used in the RT-qPCR analysis.

\begin{tabular}{|c|c|c|c|c|}
\hline Gene Name & Forward Sequence $\left(5^{\prime} \rightarrow 3^{\prime}\right)$ & Reverse Sequence $\left(5^{\prime} \rightarrow 3^{\prime}\right)$ & Annealing Temperature $\left({ }^{\circ} \mathrm{C}\right)$ & Size $(b p)$ \\
\hline $\begin{array}{c}\mathrm{Ca}^{2+} \text {-transporting ATPase plasma } \\
\text { membrane-type-like }\end{array}$ & GCAACCTCTGTTCCTGCAAT & ACAGTTGAGGGATGGGTTCA & 60.31 & 120 \\
\hline Myb25 Transcription factor & TGTGCTGTGGAGATGGAAGA & AGCGTTACGGATCATTTTGG & 60.18 & 154 \\
\hline WRKY54 Transcription factor & TTTCCGTCTTCCTCTCATGG & ATGACCTGTGGGCAGTTGTT & 60.31 & 132 \\
\hline Universal stress protein A-like & AGCСТCССAAAGCTACCAAT & TATCAAGAACCTCCGGATCG & 60.07 & 135 \\
\hline Late embryogenesis abundant protein D-34-like & TCTCGGGTGCTACTGAGAAA & ACGGCAGGAAATCACATCTT & 59.08 & 181 \\
\hline
\end{tabular}

\subsection{Statistical Analyses}

Statistical analyses were performed with SPSS 21 software package (IBM SPSS Statistics, USA). Firstly, the normality of all data was determined by the Kolmogorov-Smirnov test. ANOVA was used to test for significant differences between treatments, genotypes, and among hours in data with a normal distribution. Statistical significance was assessed with Tukey's test $(p \leq 0.05)$. Data in which the assumption of normality was not met at the level of $95 \%$ confidence were undergone to non-parametric Kruskal-Wallis' test $(p<0.05)$. Student's $t$-test $(p \leq 0.05)$ was applied to analyze the statistical differences between treatments and between genotypes for each time point of the previous confirmation of normal distribution.

In addition, in order to determine the relation among physiological parameters and biochemical response, Pearson correlation coefficient for parametric data and Spearman 
(Rho) correlation coefficient for non-parametric data $(p<0.01)$ were calculated, as well as each regression analysis for each correlated parameter.

\section{Results and Discussion}

\subsection{Physiological and Biochemical Changes in Response to Drought at Short-Term}

Under drought stress, plants survive to unfavorable environmental conditions developing different response mechanisms that lead to drought resistance. These mechanisms are classified into three strategies: escape, avoidance, and tolerance to drought stress [30]. Depending on the strategy followed by plants during drought exposure, different changes at physiological, biochemical, and molecular levels will be activated as a result of triggering numerous signaling pathways $[9,31]$. Abscisic acid (ABA) is a crucial phytohormone that acts as a secondary messenger regulating several physiological responses, including stomatal closure to reduce transpiration rate [32,33], which result in an improvement of drought avoidance, as well as inducing the most important drought-stress-responsive gene network in plants that allow for osmotic adjustment, cell membrane stability, and regulation in plant growth $[34,35]$ to enhance the drought tolerance of the plant. Several of these response mechanisms can be studied as a result of physiological effects to drought stress evaluated by the determination of the stomatal conductance (gs), the leaf water potential (LWP), the relative water content, (RWC), and the electrolyte leakage (EL). These parameters have been extensively applied to assess drought stress conditions in plants $[12,13,36]$.

In the present work, during the drought stress period, drought-stressed plants of both genotypes showed a significant and exponential increase in their root ABA content from $2 \mathrm{ng} \mathrm{g}^{-1}(0 \mathrm{~h})$ to $27 \mathrm{ng} \mathrm{g}^{-1}(24 \mathrm{~h})$ in 'Garnem' and from $4.2 \mathrm{ng} \mathrm{g}^{-1}(0 \mathrm{~h})$ to $46 \mathrm{ng} \mathrm{g}^{-1}$ (24 h) in Myrobalan 'P.2175' (Figure 2). Therefore, the root ABA content in the plum was significantly higher than the ABA content in 'Garnem' roots in both time points: $3 \mathrm{~h}$ and $24 \mathrm{~h}$. On the other side, root ABA content was constant without statistical differences throughout the experiment in well-watered plants, presenting an average ABA level of $2.79 \mathrm{ng} \mathrm{g}^{-1}$ in 'Garnem' and of $3.50 \mathrm{ng} \mathrm{g}^{-1}$ in Myrobalan 'P.2175' (Figure 2).

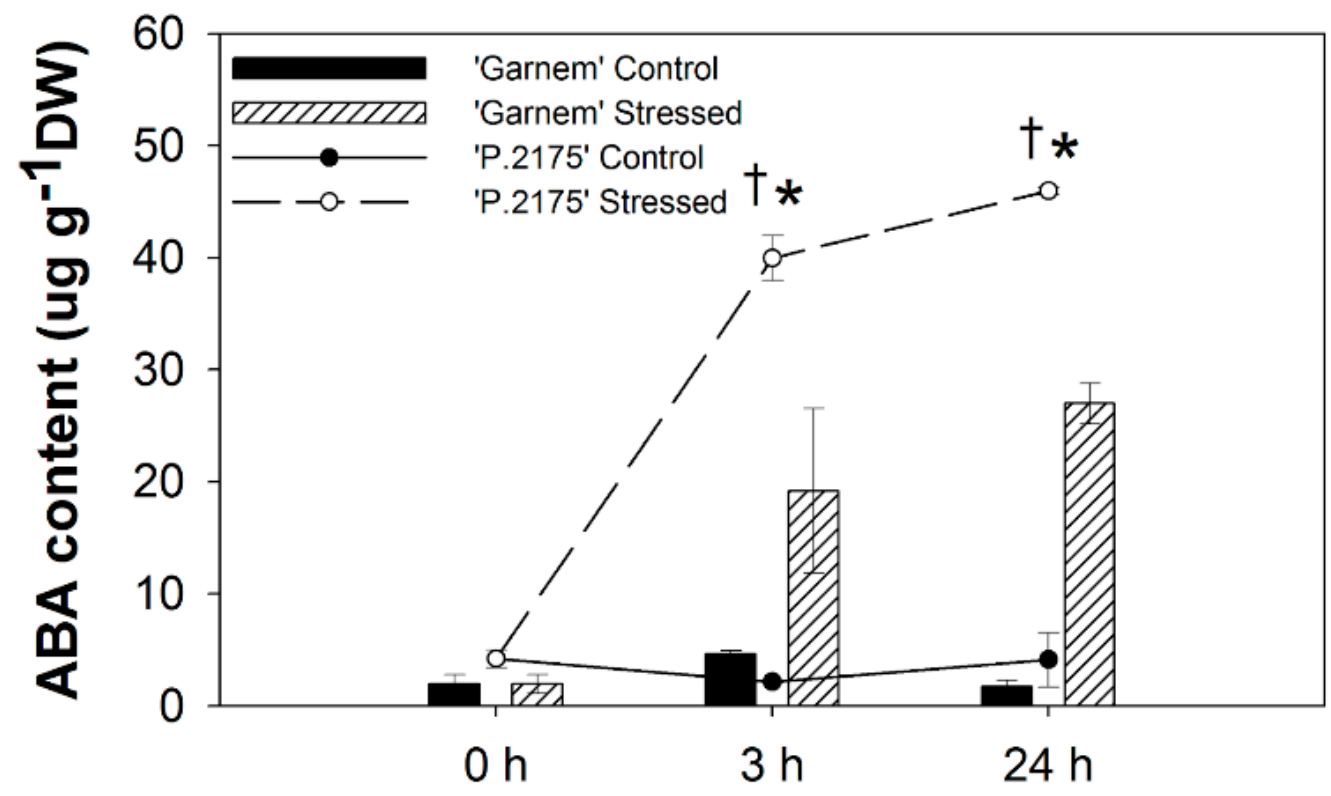

Figure 2. Abscisic acid (ABA) content during the drought experiment. Error bars represent the standard error of the mean. (MS = dried weight). *: significant differences $(p \leq 0.05)$ following the Student's $t$-test between genotypes ('Garnem' vs. Myrobalan 'P.2175') for each time point of the experiment $(0 \mathrm{~h}-3 \mathrm{~h}-24 \mathrm{~h})$; + : significant differences $(p \leq 0.05)$ following the Student's $t$-test between treatments (control vs. drought stress) for each time point of the experiment. $h=$ hour. 
During the non-irrigation period, stressed plants experienced visual symptoms such as leaf decline and desiccation, which were more evident at $24 \mathrm{~h}$ of drought stress in both leaves and rooted part of 'Garnem' and Myrobalan 'P.2175' (Figure 1). Drought-related physiological rates including LWP, gs, RWC, and EL were evaluated, and their results are shown in Figure 3. In stressed plants from both genotypes, LWP decreased significantly at $3 \mathrm{~h}$ of drought treatment, while control plants maintained stable their LWP values for the duration of the experiment, which confirms water stress exposure (Figure 3a). At that same time point, statistically significant differences were also observed between genotypes in stressed plants. Stressed Myrobalan 'P.2175' plants reached a significantly lower LWP rate $(-1.64 \mathrm{MPa})$ than stressed 'Garnem' plants $(-1.48 \mathrm{MPa})$ (Figure 3a. At $24 \mathrm{~h}$, the LWP rate in stressed 'Garnem', increased close to control plants but showed significant differences in comparison to the control plants. However, Myrobalan 'P.2175' decreased until the lowest value of $-1.73 \mathrm{MPa}$ (Figure 3a). During the drought experiment, the gs values presented significant differences between treatments at $3 \mathrm{~h}$ and $24 \mathrm{~h}$, and between genotypes in each treatment at $24 \mathrm{~h}$ (Figure $3 \mathrm{~b}$ ). Stressed plants declined significantly their gs values in comparison to control plants, but without differences between genotypes at $3 \mathrm{~h}$ of drought stress (Figure 3b). These statistical differences were observed at $24 \mathrm{~h}$ of drought stress when the gs value in stressed 'Garnem' was similar as the gs value reached at $3 \mathrm{~h}$, meanwhile Myrobalan 'P.2175' dropped until a gs value of $27.18 \mathrm{mmol} \mathrm{m}^{-2} \mathrm{~s}^{-1}$ (Figure 3b). The high increment of ABA content in the roots together with the gs values reached in drought-stressed plants of both genotypes during the drought exposure (Figures 2 and 3) indicated a rapid long-distance hydraulic signal from root to shoot, inducing the stomatal closure [37] at $3 \mathrm{~h}$ and then, avoiding the water losses during the drought exposure. Indeed, the stomatal conductance (gs) dropped at $24 \mathrm{~h}$ of drought stress (Figure 3a), which would suggest a rapid control over the gas exchange during drought stress, as previously demonstrated in grapevine [13]. However, the water losses were different between droughtstressed genotypes. When the RWC and EL rates were evaluated, significant differences between treatments were only observed at $24 \mathrm{~h}$ of drought exposure in both parameters (Figure 3c,d). While stressed plants of 'Garnem' showed an RWC rate of $60.66 \%$, the RWC rate in stressed Myrobalan 'P.2175' was 48.11\% (Figure 3c). In addition, although EL rates were similar at $3 \mathrm{~h}$ in both treatments and genotypes, at $24 \mathrm{~h}$ of drought stress, the EL rate of Myrobalan 'P.2175' increased dramatically until a value of $56.74 \%$, showing significant differences in comparison to the other time points in the experiment. However, stressed 'Garnem' reached a lower EL rate of 31.9\% (Figure 3d). All these data suggest a better osmotic adjustment and a higher cell membrane stability in 'Garnem', which maintained its water status, than in the Myrobalan, both processes triggered by ABA accumulation [11]. In a recent study, Bellvert et al. [38] also observed that 'Garnem' is able to maintain high water potentials under depravation water regimens, in contrast to other rootstocks having Myrobalan plum as one of their parents such as the 'Rootpac' series, confirming in that way our results. The authors suggest that these evidences are related to the different vigor and capability of water absorption by the root system.

Pearson correlation coefficient $(\mathrm{r})$ between the physiological parameters was analyzed showing a high correlation $(\mathrm{r}<0.70)$ between the LWP and the gs values $(\mathrm{r}=0.788 ; p<0.01)$ (Figure 4a) and between RWC and EL rates ( $r=-0.927 ; p<0.01)$ (Figure $4 \mathrm{~d}$ ). The gs values showed a moderate correlation $(0.30 \leq r \leq 0.70)$ with the RWC and the EL rates $(r=0.619$ and $r=-0.616$, respectively; $p<0.05$ ) (Figure $4 b, c)$. In addition, when the correlation between physiological and biochemical parameters was analyzed, a high correlation was found between ABA values and LWP and gs values $(r=-0.773$ and $r=-0.814$, respectively; $p<0.01$ ) (Figure 4e,f), as well as a moderate correlation shown between ABA values and RWC and EL rates ( $\mathrm{r}=-0.613$ and $\mathrm{r}=-0.670$, respectively; $p<0.05)$ (Figure $4 \mathrm{~g}, \mathrm{~h}$ ). These results indicated the high relationship between the physiological and the biochemical response to drought stress, in which the stomatal closure is regulated by the ABA accumulation to maintain the leaf water status $[13,37]$. Similar correlation between the physiological and the biochemical responses has been reported in grapevine [13] and almond [39]. 


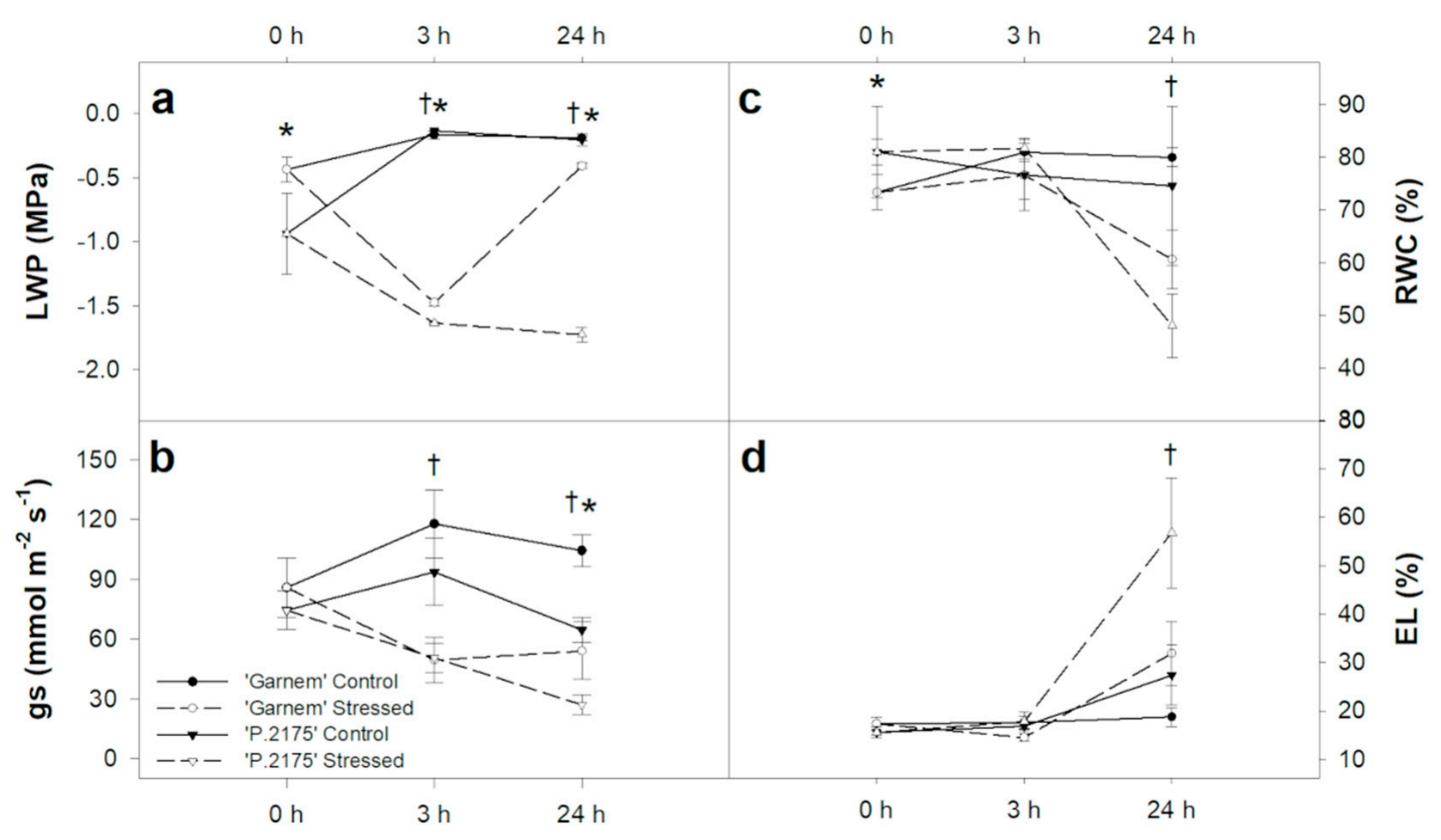

Figure 3. Evolution of (a) leaf water potential (LWP); (b) stomatal conductance (gs); (c) relative water content (RWC); and (d) electrolyte leakage (EL) during the drought experiment. Error bars represent the standard error of the mean. *: significant differences $(p \leq 0.05)$ following the Student's $t$-test between genotypes ('Garnem' vs. Myrobalan 'P.2175') for each time point ( 0 h-3 h-24 h) and for each treatment (control vs. tressed) of the experiment; + : significant differences $(p \leq 0.05)$ following the Student's $t$-test between treatments (control vs. drought stress) for each time point of the experiment. $\mathrm{h}=\mathrm{hour}$.

\subsection{Gene Regulation during Short-Term-Drought Response}

A transcriptome approach conducted in a previous work resulted in a set of differentially expressed genes during a short-time drought stress in 'Garnem' roots [40]. Briefly, the gene encoding a $\mathrm{Ca}^{2+}$-transporting ATPase plasma membrane-type-like ( $\mathrm{Ca}^{2+}$-ATPase like) as a secondary messenger; two transcription factors (TFs): the MYB25-like TF and the WRKY54 TF; a gene encoding an universal stress protein A-like protein (uspA-like); and a gene encoding a late embryogenesis abundant protein D-34-like ( $L E A-D$-34-like) were selected (Table 1) to study the changes in gene expression patterns responding to drought stress in two different Prunus genotypes, the drought-sensitive Myrobalan 'P.2175' and the drought-tolerant 'Garnem'.

In the present study, differences in gene expression were found in stressed plants compared with the expression level in well-watered plants, except for uspA-like that did not show differential changes in its expression in both genotypes and treatments (Figure 5a). The uspA is a family of proteins present in multiple organisms with the capability to respond to abiotic stresses [41]. In plants, the role of these proteins in improving the tolerance to drought, salt, and extreme temperatures has been widely demonstrated [42-45]. However, in these previous studies, plants experienced a long-term exposure (days) to adverse conditions. Based on that, the lack of uspA-like differential expression in our genotypes could be because the drought exposure was at short-term $(24 \mathrm{~h})$ conditions. Then, there was not enough time to induce the response to drought stress for this gene.

Calcium $\left(\mathrm{Ca}^{2+}\right)$ plays an important role as a second messenger in abiotic stress response. When stress stimulus is produced, $\mathrm{Ca}^{2+}$ channels are activated in the plasma membrane and ions mobilized into the cell, causing a $\mathrm{Ca}^{2+}$ accumulation. This $\mathrm{Ca}^{2+}$ binds to calmodulin $(\mathrm{CaM})$ and calcium-activated phosphatases/kinases triggering a signal transduction cascade in plants. As a result, induction of stomatal closure and production of reactive oxygen species are provoked under drought stress [46-48]. $\mathrm{Ca}^{2+}$-ATPases are 
found among enzymes involved in $\mathrm{Ca}^{2+}$ signaling pathway in response to drought and salinity. These enzymes are implicated in the modulation of the low $\mathrm{Ca}^{2+}$ concentration in the cytosol [49]. The expression of a $\mathrm{Ca}^{2+}$-ATPase-like, homologous to AtACA4, was found differentially overexpressed from $3 \mathrm{~h}$ of the drought exposure in both genotypes reaching the highest levels of expression in Myrobalan 'P.2175' in comparison to 'Garnem' (Figure 5b). Geisler et al. [50] confirmed that AtACA4 is activated by CaM and protects against osmotic stress in yeast. In addition, aca4 and aca11 knockout mutants in Arabidopsis activated SA-dependent programmed cell death pathway in response to salinity [51]. Our results would evidence that $\mathrm{Ca}^{2+}$-ATPase-like was also involved in drought stress response in Prunus.
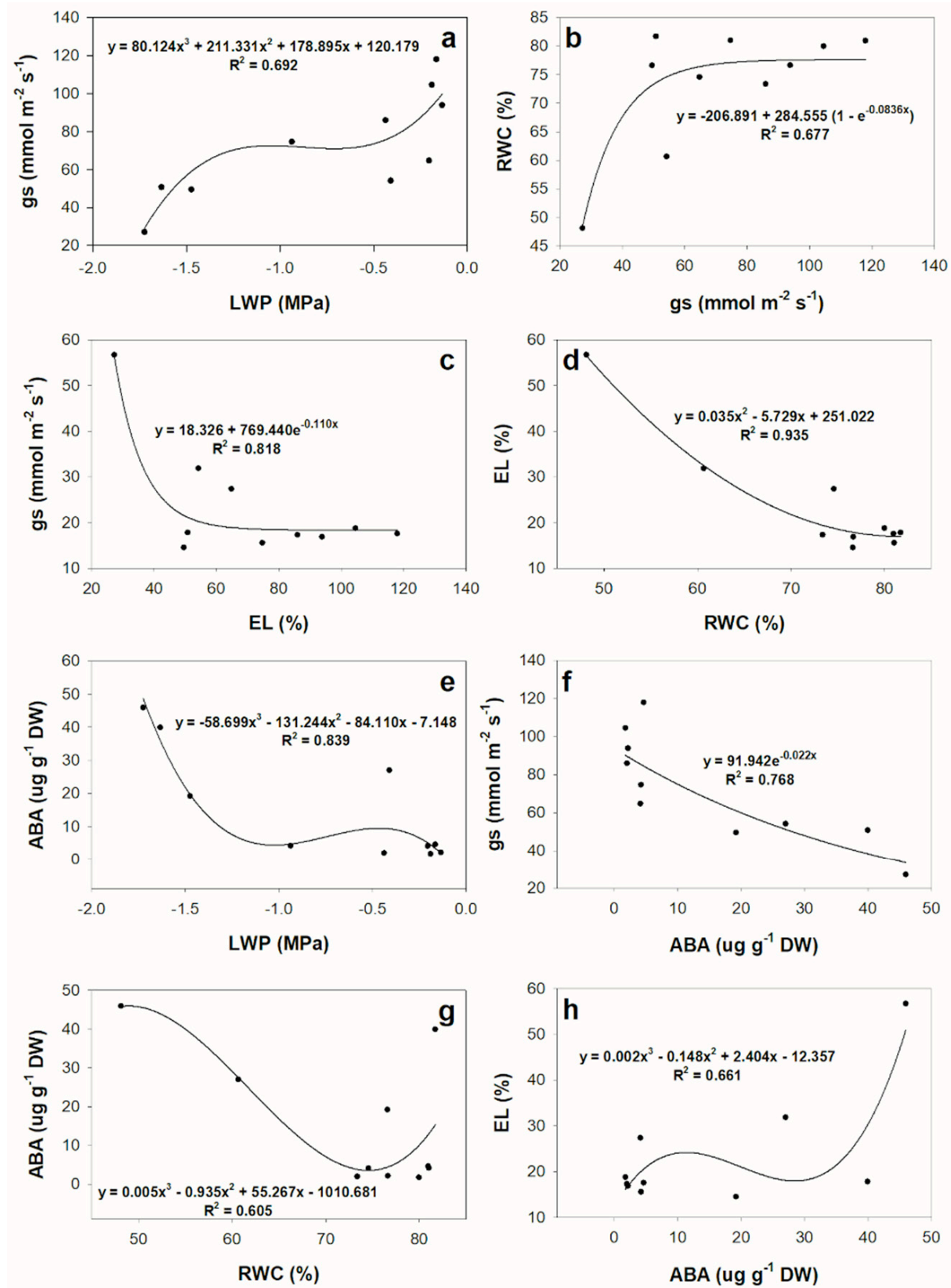

Figure 4. (a) Relationship between leaf water potential (LWP) and stomatal conductance (gs); (b) relationship between gs and relative water content (RWC); (c) relationship between electrolyte leakage (EL) and gs; (d) relationship between RWC and EL; (e) relationship between LWP and abscisic acid (ABA) content; (f) relationship between ABA and gs; (g) relationship between RWC and ABA; finally, (h) relationship between EL and ABA. Each value is a single measurement. 

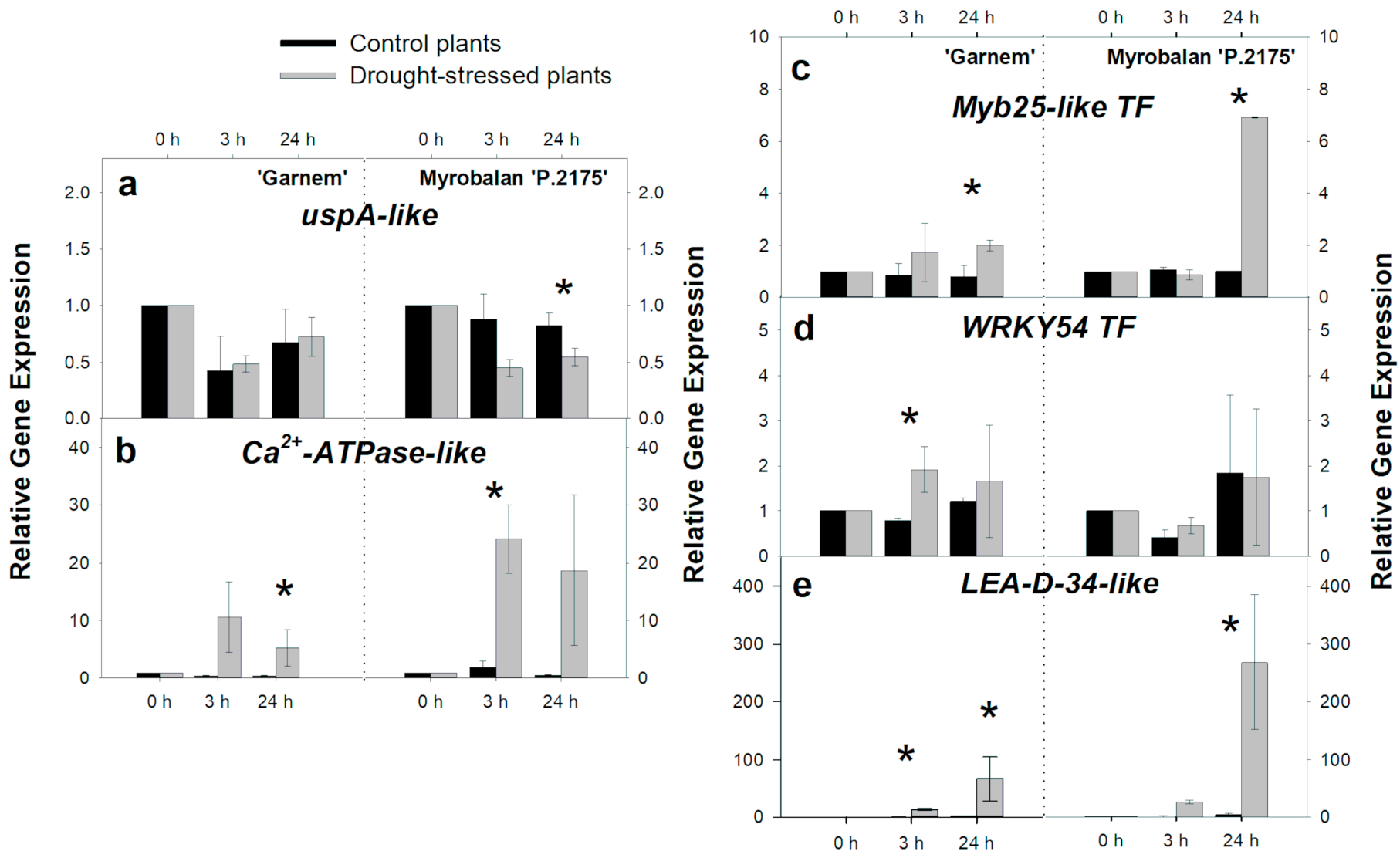

Figure 5. Relative expression of (a) universal stress protein A-like protein (uspA-like); (b) Ca ${ }^{2+}$-transporting ATPase plasma membrane-type-like (Ca ${ }^{2+}$-ATPase-like); (c) Myb25-like transcription factor (Myb25-like TF); (d) WRKY54 transcription factor (WRKY54 TF); and (e) late embryogenesis abundant protein D-34-like (LEA-D-34-like). Expression levels were compared to the TEF2 gene. The relative value of 1 was assigned to the sample on hour 0 (control time-point value). Data show the average relative expression of two biological samples with three technical replicates of each one. Error bars represent the standard error of the mean. Asterisks $\left(^{*}\right)$ indicate significantly different expression values $(p \leq 0.05)$ following the Student's $t$-test between treatments (control vs. drought stress) within each genotype ('Garnem' vs. Myrobalan 'P.2175') for each time point of the experiment $(0 \mathrm{~h}-3 \mathrm{~h}-24 \mathrm{~h})$.

The ABA-related TFs Myb25-like and WRKY54 were evaluated showing a different response between well-watered and stressed plants in both genotypes (Figure $5 c, d)$. The expression of Myb25-like TF was 6x significantly higher in stressed Myrobalan 'P.2175' plants than in well-watered plum plants at $24 \mathrm{~h}$ of drought stress. At $24 \mathrm{~h}$, 'Garnem' showed statistical differences between well-watered and stressed plants (Figure 5c); however, as these differences presented a fold of change (FC) of 1.5, they were not relevant to evidence a differential change (FC > 2) in Myb25-like expression in stressed Garnem' plants compared to well-watered 'Garnem' plants (Figure 5). This gene, homologous to AtMyb44, is implicated in growth and developmental processes in P. persica [52] and G. hirsutum [53]. Although there are evidences that overexpression of $M y b 44$ improves drought tolerance by stomatal closure via ABA signaling [54], the role of this gene in drought response is controversial. Thus, Jaradat et al. [55] demonstrated that AtMyb44 is a negative regulator of ABA signaling in order to maintain growth processes during abiotic stresses. Based on this assumption, the overexpression of Myb25-like in stressed Myrobalan 'P.2175' plants could cut off the signal induced by ABA accumulation blocked the adaptive response in this genotype. While in 'Garnem', Myb25-like was not expressed to allow for drought adaptation. In case of the expression of WRKY54, the values reached by stress plants in both genotypes were not relevant to imply a differential change in its expression in comparison with the values showed by well-watered plants (Figure 5d). WRKYs, implicated in ABA-mediated stomatal closure, consequently increases in drought tolerance [56]. This TF acts as an inhibitor of 
dehydration-inducible genes negatively regulating the response of drought tolerance via Brassinosteroids (BR) signaling pathway [57]. In addition, wrky54 Arabidopsis mutants exposed to dehydration showed ABI5 induction, indicating a BR-regulated ABA signaling under drought stress via WRKY54 inhibition $[57,58]$. In our experiment, the lack of evident changes in WRKY54 expression under drought stress could indicate that the ABA signaling was not impaired by BR-regulation, allowing the stomatal closure and then, the response to drought stress in stressed plants of both Prunus genotypes.

Finally, the relative gene expression of a $L E A-D$-34-like was analyzed in this work, finding significant changes in its expression at $24 \mathrm{~h}$ of drought exposure in stressed plants in both genotypes. The plum reached an expression level $60 \times$ higher at $24 \mathrm{~h}$ in comparison to well-watered plants, and $4 \times$ higher compared to the $L E A$-D-34-like expression level found in 'Garnem' plants at the same time-point (Figure 5e). The osmoprotecting role of LEA proteins during abiotic stresses has been extensively demonstrated in many plant species [59-62]. In our work, the overexpression of LEA-D-34-like together with the high ABA accumulation levels and the capability to maintain the water levels found in stressed plants of 'Garnem' suggest an adaptive response to drought for this genotype. However, although Myrobalan 'P.2175' triggered a molecular response by ABA accumulation under drought stress, this genotype was not able to perform an osmotic adjustment, resulting in a higher water loss.

\section{Conclusions}

The observed changes in physiological parameters, the ABA concentration and the changes found in expression of drought-responsive genes analyzed in our work suggest that 'Garnem' activated the response to stress from the first hours of drought submission, resulting in a maintenance of its homeostasis and finally, in an adaptation to drought. In Myrobalan 'P.2175', the response to stress was also initiated; however, the plum did not develop a drought-tolerant response under dehydration stress. The high overexpression of drought-responsive genes including $\mathrm{Ca}^{2+}$-ATPase-like and LEA-D-34-like, is not enough to produce an osmoprotectant response. As consequence, Myrobalan 'P.2175' is not able to perform as osmotic adjustment. These results evidence the great potential of 'Garnem' as a drought tolerance source for further crosses in breeding. In addition, based on our data, we propose the Myb25 TF as a biomarker of drought sensitivity for use in Prunus rootstock breeding programs.

Author Contributions: Conceptualization, B.B. and M.J.R.-C.; methodology, B.B., M.Á.S. and M.J.R.-C.; validation, B.B., M.Á.S. and M.J.R.-C.; formal analysis, B.B. and M.Á.S.; investigation, B.B. and M.Á.S.; resources, M.J.R.-C.; data curation, B.B. and M.Á.S.; writing—original draft preparation, B.B.; writing—review and editing, B.B., M.Á.S. and M.J.R.-C.; visualization, B.B.; supervision, M.J.R.-C.; project administration, M.J.R.-C.; funding acquisition, M.J.R.-C. All authors have read and agreed to the published version of the manuscript.

Funding: This research was funded by Agencia Estatal de Investigación (AEI) Project no. RTI2018094210-R100, as well as by the Gobierno de Aragón-European Social Fund, European Union (Grupo Consolidado A12), and The APC funded by Gobierno de Aragón-European Social Fund, European Union (Grupo Consolidado A12).

Institutional Review Board Statement: Not applicable.

Informed Consent Statement: Not applicable.

Conflicts of Interest: The authors declare no conflict of interest.

\section{References}

1. Rehder, A. A Manual of Cultivated Trees and Shrubs Hardy in North America; The MacMillan Company: New York, NY, USA, 1940.

2. Layne, R.E.C. Peach Rootstocks. In Rootstocks for Fruit Crops; Rom, R.C., Carlson, R.F., Eds.; Wiley: New York, NY, USA, 1987; pp. $185-216$.

3. Felipe, A.J. 'Felinem', 'Garnem', and 'Monegro' almond $\times$ peach hybrid rootstocks. HortScience 2009, 44, 196-197. [CrossRef] 
4. Rubio-Cabetas, M.J.; Felipe, A.J.; Reighard, G.L. Rootstock Development. In Almonds. Botany, Production and Uses; Rafel Socias i Company, Gradziel, T.M., Eds.; CABI: Wallingford, UK, 2017; pp. 209-227. ISBN 9781845933869.

5. IPCC. Summary for Policymakers. In Global Warming of $1.5^{\circ} \mathrm{C}$. An IPCC Special Report on the Impacts of Global Warming of $1.5^{\circ} \mathrm{C}$ above Pre-Industrial Levels and Related Global Greenhouse Gas Emission Pathways, in the Context of Strengthening the Global Response to the Threat of Climate Change, Sustainable Development, and Effors to Erradicate Poverty; Masson-Delmotte, V., Zhai, P., Ho, P., Roberts, D., Skea, J., Shukla, P., Pirani, A., Moufouma-Okia, W.C.P., Pidcock, R., Connors, S., et al., Eds.; World Meteorological Organization: Geneva, Switzerland, 2018; ISBN 9788578110796.

6. Tejedor, E.; de Luis, M.; Cuadrat, J.M.; Esper, J.; Saz, M.Á. Tree-ring-based drought reconstruction in the Iberian Range (east of Spain) since 1694. Int. J. Biometeorol. 2016, 60, 361-372. [CrossRef]

7. Chaves, M.M.; Flexas, J.; Pinheiro, C. Photosynthesis under drought and salt stress: Regulation mechanisms from whole plant to cell. Ann. Bot. 2009, 103, 551-560. [CrossRef]

8. Belin, C.; Thomine, S.; Schroeder, J.I. Water Balance and the Regulation of Stomatal Movements. In Abiotic Stress Adaptation in Plants: Physiological, Molecular and Genomic Foundation; Pareek, A., Sopory, S.K., Bohnert, H.J., Eds.; Springer: Dordrecht, The Netherlands, 2010; pp. 283-305. ISBN 978-90-481-3111-2.

9. Golldack, D.; Li, C.; Mohan, H.; Probst, N. Tolerance to drought and salt stress in plants: Unraveling the signaling networks. Front. Plant Sci. 2014, 5, 151. [CrossRef] [PubMed]

10. Lind, C.; Dreyer, I.; López-Sanjurjo, E.J.; von Meyer, K.; Ishizaki, K.; Kohchi, T.; Lang, D.; Zhao, Y.; Kreuzer, I.; Al-Rasheid, K.A.S.; et al. Stomatal Guard Cells Co-opted an Ancient ABA-Dependent Desiccation Survival System to Regulate Stomatal Closure. Curr. Biol. 2015, 25, 928-935. [CrossRef] [PubMed]

11. Verslues, P.E.; Agarwal, M.; Katiyar-Agarwal, S.; Zhu, J.; Zhu, J.-K. Methods and concepts in quantifying resistance to drought, salt and freezing, abiotic stresses that affect plant water status. Plant J. 2006, 45, 523-539. [CrossRef] [PubMed]

12. Bielsa, B.; Sanz, M.; Rubio-Cabetas, M. Uncovering early response to drought by proteomic, physiological and biochemical changes in the almond $\times$ peach rootstock 'Garnem'. Funct. Plant Biol. 2019, 46, 994-1008. [CrossRef] [PubMed]

13. Tombesi, S.; Nardini, A.; Frioni, T.; Soccolini, M.; Zadra, C.; Farinelli, D.; Poni, S.; Palliotti, A. Stomatal closure is induced by hydraulic signals and maintained by ABA in drought-stressed grapevine. Sci. Rep. 2015, 5, 12449. [CrossRef] [PubMed]

14. Kim, T.-H.; Böhmer, M.; Hu, H.; Nishimura, N.; Schroeder, J.I. Guard Cell Signal Transduction Network: Advances in Understanding Abscisic Acid, $\mathrm{CO}_{2}$, and $\mathrm{Ca}^{2+}$ Signaling. Annu. Rev. Plant Biol. 2010, 61, 561-591. [CrossRef] [PubMed]

15. Takahashi, F.; Kuromori, T.; Sato, H.; Shinozaki, K. Regulatory gene networks in drought stress responses and resistance in plants. In Survival Strategies in Extreme Cold and Desiccation. Advances in Experimental Medicine and Biology; Springer: Singapore, 2018; Volume 1081, pp. 189-214. ISBN 9789811312441.

16. Sauter, A.; Davies, W.; Hartung, W. The long-distance abscisic acid signal in the droughted plant: The fate of the hormone on its way from root to shoot. J. Exp. Bot. 2001, 52, 1991-1997. [CrossRef]

17. Sharp, R.E.; LeNoble, M.E. ABA, ethylene and the control of shoot and root growth under water stress. J. Exp. Bot. 2002, 53, 33-37. [CrossRef]

18. Kuromori, T.; Seo, M.; Shinozaki, K. ABA Transport and Plant Water Stress Responses. Trends Plant Sci. 2018, $23,513-522$. [CrossRef]

19. Gupta, A.; Rico-Medina, A.; Caño-Delgado, A.I. The physiology of plant responses to drought. Science 2020, 368, 266-269. [CrossRef]

20. Roychoudhury, A.; Paul, S.; Basu, S. Cross-talk between abscisic acid-dependent and abscisic acid-independent pathways during abiotic stress. Plant Cell Rep. 2013, 32, 985-1006. [CrossRef] [PubMed]

21. Arbona, V.; Iglesias, D.J.; Jacas, J.; Primo-Millo, E.; Talon, M.; Gómez-Cadenas, A. Hydrogel substrate amendment alleviates drought effects on young citrus plants. Plant Soil 2005, 270, 73-82. [CrossRef]

22. Scholander, P.F.; Hammel, H.T.; Hemmingsen, E.A.; Bradstreet, E.D. Hydrostatic Pressure and Osmotic Potential in Leaves of Mangroves and Some Other Plants. Proc. Natl. Acad. Sci. USA 1964, 52, 119-125. [CrossRef] [PubMed]

23. Barrs, H.D.; Weatherley, P.E. A re-examination of the relative turgidity technique for estimating water deficits in leaves. Aust. J. Biol. Sci. 1962, 15, 413-428. [CrossRef]

24. Blum, A.; Ebercon, A. Call membrane stability as a measure of drought and heat tolerance in wheat. Crop Sci. 1981, 21, 43-47. [CrossRef]

25. Gómez-Cadenas, A.; Pozo, O.J.; García-Augustín, P.; Sancho, J. V Direct analysis of abscisic acid in crude plant extracts by liquid chromatography-electrospray/tandem mass spectrometry. Phytochem. Anal. 2002, 13, 228-234. [CrossRef]

26. Meisel, L.; Fonseca, B.; González, S.; Baeza-Yates, R.; Cambiazo, V.; Campos, R.; González, M.; Orellana, A.; Retamales, J.; Silva, H. A Rapid and Efficient Method for Purifying High Quality Total RNA from Peaches (Prunus persica) for Functional Genomics Analyses. Biol. Res. 2005, 38, 83-88. [CrossRef]

27. Chang, S.; Puryear, J.; Cairney, J. A simple and efficient method for isolating RNA from pine trees. Plant Mol. Biol. Rep. 1993, 11, 113-116. [CrossRef]

28. Salzman, R.A.; Fujita, T.; Zhu-Salzman, K.; Hasegawa, P.M.; Bressan, R.A. An Improved RNA Isolation Method for Plant Tissues Containing High Levels of Phenolic Compounds or Carbohydrates. Plant Mol. Biol. Rep. 1999, 17, 11-17. [CrossRef]

29. Zeng, Y.; Yang, T. RNA Isolation from Highly Viscous Samples Rich in Polyphenols and Polysaccharides. Plant Mol. Biol. Rep. 2002, 20, 417. [CrossRef] 
30. Basu, S.; Ramegowda, V.; Kumar, A.; Pereira, A. Plant adaptation to drought stress. F1000Research 2016, 5, 1554. [CrossRef]

31. Osakabe, Y.; Osakabe, K.; Shinozaki, K.; Tran, L.-S.P. Response of plants to water stress. Front. Plant Sci. 2014, 5, 86. [CrossRef] [PubMed]

32. Basu, S.; Rabara, R. Abscisic acid-An enigma in the abiotic stress tolerance of crop plants. Plant Gene 2017, 11, 90-98. [CrossRef]

33. Negin, B.; Moshelion, M. The evolution of the role of ABA in the regulation of water-use efficiency: From biochemical mechanisms to stomatal conductance. Plant Sci. 2016, 251, 82-89. [CrossRef] [PubMed]

34. Yamaguchi-Shinozaki, K.; Shinozaki, K. Transcriptional Regulatory Networks in Cellular Responses and Tolerance to Dehydration and Cold Stresses. Annu. Rev. Plant Biol. 2006, 57, 781-803. [CrossRef]

35. Shinozaki, K.; Yamaguchi-Shinozaki, K. Gene networks involved in drought stress response and tolerance. J. Exp. Bot. 2007, 58, 221-227. [CrossRef]

36. Bolat, I.; Dikilitas, M.; Ercisli, S.; Ikinci, A.; Tonkaz, T. The effect of water stress on some morphological, physiological, and biochemical characteristics and bud success on apple and quince rootstocks. Sci. World J. 2014, 2014, 769732. [CrossRef]

37. Christmann, A.; Grill, E.; Huang, J. Hydraulic signals in long-distance signaling. Curr. Opin. Plant Biol. 2013, 16, 293-300. [CrossRef]

38. Bellvert, J.; Nieto, H.; Pelechá, A.; Jofre-Čekalović, C.; Zazurca, L.; Miarnau, X. Remote Sensing Energy Balance Model for the Assessment of Crop Evapotranspiration and Water Status in an Almond Rootstock Collection. Front. Plant Sci. 2021, 12, 288. [CrossRef]

39. Spinelli, G.M.; Snyder, R.L.; Sanden, B.L.; Shackel, K.A. Water stress causes stomatal closure but does not reduce canopy evapotranspiration in almond. Agric. Water Manag. 2016, 168, 11-22. [CrossRef]

40. Bielsa, B.; Hewitt, S.; Reyes-Chin-Wo, S.; Dhingra, A.; Rubio-Cabetas, M.J. Identification of water use efficiency related genes in 'Garnem' almond-peach rootstock using time-course transcriptome analysis. PLoS ONE 2018, 13, e205493. [CrossRef]

41. Isokpehi, R.D.; Simmons, S.S.; Cohly, H.H.P.; Ekunwe, S.I.N.; Begonia, G.B.; Ayensu, W.K. Identification of drought-responsive universal stress proteins in Viridiplantae. Bioinform. Biol. Insights 2011, 5, 41-58. [CrossRef]

42. Sinha, P.; Pazhamala, L.T.; Singh, V.K.; Saxena, R.K.; Krishnamurthy, L.; Azam, S.; Khan, A.W.; Varshney, R.K. Identification and Validation of Selected Universal Stress Protein Domain Containing Drought-Responsive Genes in Pigeonpea (Cajanus cajan L.). Front. Plant Sci. 2016, 6, 1065. [CrossRef]

43. Udawat, P.; Jha, R.K.; Sinha, D.; Mishra, A.; Jha, B. Overexpression of a Cytosolic Abiotic Stress Responsive Universal Stress Protein (SbUSP) Mitigates Salt and Osmotic Stress in Transgenic Tobacco Plants. Front. Plant Sci. 2016, 7, 518. [CrossRef] [PubMed]

44. Bhuria, M.; Goel, P.; Kumar, S.; Singh, A.K. The Promoter of AtUSP Is Co-regulated by Phytohormones and Abiotic Stresses in Arabidopsis thaliana. Front. Plant Sci. 2016, 7, 1957. [CrossRef] [PubMed]

45. Yang, M.; Che, S.; Zhang, Y.; Wang, H.; Wei, T.; Yan, G.; Song, W.; Yu, W. Universal stress protein in Malus sieversii confers enhanced drought tolerance. J. Plant Res. 2019, 132, 825-837. [CrossRef] [PubMed]

46. Jing, X.; Cai, C.; Fan, S.; Wang, L.; Zeng, X. Spatial and temporal calcium signaling and its physiological effects in Moso Bamboo under drought stress. Forests 2019, 10, 224. [CrossRef]

47. Shinozaki, K.; Yamaguchi-Shinozaki, K. Gene Expression and Signal Transduction in Water-Stress Response. Plant Physiol. 1997, 115, 327-334. [CrossRef]

48. Knight, H. Calcium signaling during abiotic stress in plants. Int. Rev. Cytol. 1999, 195, 269-324. [CrossRef]

49. Huda, K.M.K.; Yadav, S.; Banu, M.S.A.; Trivedi, D.K.; Tuteja, N. Genome-wide analysis of plant-type II Ca ${ }^{2+}$ ATPases gene family from rice and Arabidopsis: Potential role in abiotic stresses. Plant Physiol. Biochem. 2013, 65, 32-47. [CrossRef]

50. Geisler, M.; Frangne, N.; Gomès, E.; Martinoia, E.; Palmgren, M.G. The ACA4 gene of Arabidopsis encodes a vacuolar membrane calcium pump that improves salt tolerance in yeast. Plant Physiol. 2000, 124, 1814-1827. [CrossRef] [PubMed]

51. Boursiac, Y.; Lee, S.M.; Romanowsky, S.; Blank, R.; Sladek, C.; Chung, W.S.; Harper, J.F. Disruption of the Vacuolar CalciumATPases in Arabidopsis Results in the Activation of a Salicylic Acid-Dependent Programmed Cell Death Pathway. Plant Physiol. 2010, 154, 1158-1171. [CrossRef] [PubMed]

52. Vendramin, E.; Pea, G.; Dondini, L.; Pacheco, I.; Dettori, M.T.; Gazza, L.; Scalabrin, S.; Strozzi, F.; Tartarini, S.; Bassi, D.; et al. A unique mutation in a MYB gene cosegregates with the nectarine phenotype in peach. PLoS ONE 2014, 9, e90574. [CrossRef]

53. Machado, A.; Wu, Y.; Yang, Y.; Llewellyn, D.J.; Dennis, E.S. The MYB transcription factor GhMYB25 regulates early fibre and trichome development. Plant J. 2009, 59, 52-62. [CrossRef]

54. Jung, C.; Jun, S.S.; Sang, W.H.; Yeon, J.K.; Chung, H.K.; Sang, I.S.; Baek, H.N.; Yang, D.C.; Cheong, J.J. Overexpression of AtMYB44 enhances stomatal closure to confer abiotic stress tolerance in transgenic Arabidopsis. Plant Physiol. 2008, 146, 623-635. [CrossRef] [PubMed]

55. Jaradat, M.R.; Feurtado, J.A.; Huang, D.; Lu, Y.; Cutler, A.J. Multiple roles of the transcription factor AtMYBR1/AtMYB44 in ABA signaling, stress responses, and leaf senescence. BMC Plant Biol. 2013, 13, 192. [CrossRef] [PubMed]

56. Tripathi, P.; Rabara, R.C.; Rushton, P.J. A systems biology perspective on the role of WRKY transcription factors in drought responses in plants. Planta 2014, 239, 255-266. [CrossRef]

57. Chen, J.; Nolan, T.M.; Ye, H.; Zhang, M.; Tong, H.; Xin, P.; Chu, J.; Chu, C.; Li, Z.; Yina, Y. Arabidopsis WRKY46, WRKY54, and WRKY70 transcription factors are involved in brassinosteroid-regulated plant growth and drought responses. Plant Cell 2017, 29, 1425-1439. [CrossRef] 
58. Wang, Q.; Yu, F.; Xie, Q. Balancing growth and adaptation to stress: Crosstalk between brassinosteroid and abscisic acid signaling. Plant Cell Environ. 2020, 43, 2325-2335. [CrossRef] [PubMed]

59. Hundertmark, M.; Hincha, D.K. LEA (Late Embryogenesis Abundant) proteins and their encoding genes in Arabidopsis thaliana. BMC Genom. 2008, 9, 118. [CrossRef] [PubMed]

60. Du, D.; Zhang, Q.; Cheng, T.; Pan, H.; Yang, W.; Sun, L. Genome-wide identification and analysis of late embryogenesis abundant (LEA) genes in Prunus mume. Mol. Biol. Rep. 2013, 40, 1937-1946. [CrossRef] [PubMed]

61. Magwanga, R.O.; Lu, P.; Kirungu, J.N.; Lu, H.; Wang, X.; Cai, X.; Zhou, Z.; Zhang, Z.; Salih, H.; Wang, K.; et al. Characterization of the late embryogenesis abundant (LEA) proteins family and their role in drought stress tolerance in upland cotton. BMC Genet. 2018, 19, 6. [CrossRef]

62. Li, X.; Cao, J. Late Embryogenesis Abundant (LEA) Gene Family in Maize: Identification, Evolution, and Expression Profiles. Plant Mol. Biol. Rep. 2016, 34, 15-28. [CrossRef] 